\title{
A study of the interrelation between inflation and BSE consistency
}

\author{
K. Prabhakar Rajkumar
}

Assistant Professor, Periyar University, Tamil Nadu, India

*Corresponding Author:

Email: kudalkprk6@yahoo.co.in

\begin{abstract}
This study examines the relationship between WPI measured inflation and BSE market consistency proxied by market capitalization, BSE Sensex 30 and trading turnover-both value and volume, during the period April, 2000 to March, 2014. The investigation has been made by applying the vector error correction model and Johansen co-integration test. The study analysed the correlation between the variables by using Karl Pearson Coefficient of correlation matrix, further confirmed through the test of significance. All the findings of the study were justified through the correlated variables. In addition the Johansen cointegration test results show that there is a long run, but there is a negative relationship between WPI measured inflation and selected proxies of BSE consistency during the evaluated period. However, no short run interrelation between the variables also observed during the study period.
\end{abstract}

Keywords: Capital markets, Financial intermediation, Correlation, Co-integration, Vector error correction, Inflation, Market capitalization, BSE sensex 30 .

\section{Introduction}

Capital markets played a significant role in the economic development and growth, most particularly of developing economies. They supplement liquidity along with the banking sector, through effective financial intermediation. ${ }^{1}$ In the Indian context, the stock markets have grown in size, volume and global investors' participation over the last two decades. Today, Bombay stock Exchange (BSE), one of the two major stock exchanges in the country is ranked 11 among the global stock markets in terms of market capitalization and trading turnover. ${ }^{2}$ The share owning population has improved over time. It implies that the investors are attracted towards high returns, growth potential and diversification benefits of stock markets. Despite these positives, stock markets in India are characterised as the most volatile. They are sensitive to factors such as economic growth and output, political environment, international risks, interest rate, money supply, inflation etc. ${ }^{3}$ Hence, stock markets and macro-economy are said to be co-integrated. Several researchers have investigated the relationship between macro-economic factors and stock market performance at different points in time. The findings have been inconsistent. A further inquiry is always imminent. Out of the economic factors, the present study has identified inflation and has attempted to test its relationship with BSE consistency during the period April 1, 2000 to March 31 , 2014. Further, in order to achieve uniformity and parallelity of the time series data, the study uses the natural logarithm of the raw data concerning inflation and BSE consistency, proxied by market capitalisation, BSE Sensex 30 and turnover - both value and volume. WPI measured inflation, which was the independent variable while BSE consistency was the dependent variable.

\section{Statement of Problem}

Every investment entails risk irrespective of the form or the location. Stocks as a class of financial assets are no exception. Stocks are subject to a variety of risks such as business risk, liquidity risk, inflation risk, international risks etc. Among various risks, inflation is widely debated, inflation being a systematic risk. Inflation shrivels the rupee and investment value. Whereas in India, inflation concerns every section of the society as well as the Government. Food inflation is said to be the major driver of overall inflation as agriculture is the mainstay of the majority population and is monsoon and rainfall dependent. On an average, about $49 \%{ }^{4}$ of the monthly household expenditure of the rural population are on food while it is about 39 percent for urban population. Inflation management is the most important objectives of budget policy. In the course of inflation management, any tightening of credit under monetary policy prompts control of inflation as also effects lowering of stock prices. The drop out in stock prices is on account of deteriorating demand for stocks in the red to lesser funds available for investment. Additionally, inflation and Stock prices are apt to shift in parallel paths.

It is normally held faith that stock markets are intrinsically unstable. Refer to emerging markets like India, it is additional so because of the uncertainties in the height of economic development and other factors. The worldwide risks that radiate owing to the financial and economic integration make the stock markets volatile. There have been consistent researches on the role of economic factors on stock market performance. Those studies have largely been conducted involving developed markets as well as African countries. They have been made at different times. Eventually, the findings have been divergent. While Irving Fischer ${ }^{4}$ viewed that stocks are stable against inflation and can 
hedge inflation, many other researchers, namely Fama (1981, 1983), ${ }^{5}$ Modigliani and Cohn $(1979)^{6}$ have examined an adverse relationship between the two, on differing hypotheses. However, the studies concerning Asian economies are limited and the findings have been inconclusive. In the Indian context, a cut off between inflation and the stock market is apparent as equally inflation and stock market performance have been moving together since the year 2003-04. GDP, savings, FIIs etc. also shows a rise. After the global economic meltdown of the year 2008, the Indian economy gradually recovered and recorded higher GDP, even higher the study period average. On the other side the rate of inflation as well continued high. Market performance, which is reflected by BSE Sensex 30 as well as market capitalization during that period progressed. The trend reveals that the economy beats inflation, which is not a usual phenomenon. Stock inflation nexus therefore remains as a puzzle and is even a vexing issue. In this dimension, the researcher has identified the research objective for further testing and analysis.

\section{Objective of the Study}

The purpose of the study is to bring out the interrelation between WPI measured inflation and Bombay Stock Exchange market consistency, refer to long and short run during the period April 2000 to March 31, 2014.

\section{Review of Literature}

In order to acquire the wisdom of the earlier researchers on the related topic, the researcher has reviewed the previous literature, both the global and the Indian context, and summarised a few findings in the following paragraphs.

Bhattacharya and Mukherjee (2006) ${ }^{5}$ evaluated the correlation between seven macroeconomic variables and Indian stock market for the period April 1992 to March 2001. Their findings revealed that there is no causal linkage between stock returns and money supply, IIP, GNP, real effective exchange rate, foreign exchange reserves and trade balance. A bi-directional causality was seen between stock returns and the rate of inflation.

Bruno Solnik $(1983)^{6}$ analysed the relation between security returns and inflationary expectations for nine countries over the period 1971-80 by using interest rates as a proxy for expected inflation. He concluded that stock price movements are negatively related to revisions in inflationary expectations. The interest rate revision pushes up the cost of funds used in business which increase the cost of production. This leads to inflation.

Carolene Geetha, Rosliemohidin, Vivin Vincent Chandran and Victoria Chong (2011) ${ }^{7}$ studied to recognize the association between the stock market, expected and an unexpected inflation rate, GDP and interest rate refer to the countries such as Malaysia, United States and China and have shown that there is long run co-integration relationship between stock markets and those variables in Malaysia, US and China. Stock market returns, according to them, may be adversely affected by inflationary pressures because they may threaten future corporate profits and nominal discount rates rise under inflationary pressures reducing the current value of future profits.

Dr. Sarbapriya Ray $(2012)^{8}$ found the relationship between the stock prices and inflation in the aspect of assessing the effects of inflation on stock prices of India, Hong Kong, Singapore, Japan and Korea during 2002 to 2010. The long run relationship exists between the inflation rate and stock prices were identified in Hong Kong and Singapore and short run were identified in India and Korea. Inflation and stock prices are positively associated with most of the cases and therefore stocks are a perfect hedge against inflation and that in case of Korea only, stock prices are negatively related to inflation indicating that stock prices are not a good hedge against inflation.

Farzafarsio and Shokoofehfazel $(2008)^{9}$ examined the question of the predictive power of inflation data to determine the stock prices. He indicated against the general understanding that a declining stock market is associated with rising inflation rates and vice versa, and that there should not be any stable and significant causal relation from inflation to stock prices. They concluded that making long term investment in the security market should not be relied upon inflation data.

Gautam Kaul (1987) ${ }^{10}$ evaluated the relation between inflation and stock returns as a causal effect of the equilibrium process in the monetary sector and evidenced that that the negative stock return-inflation relations are caused by forces of money demand and money supply effects. Money supply growth is an important factor causing price level changes in an economy.

K. R. Shanmugham and Biswaswarup Mistra $(2008)^{11}$ have conducted a study to test the efficiency at which inflation is related to stock returns in India. They have rejected the Fischer hypothesis to conclude that stock returns and unexpected inflation are negatively related for a length of time. Real activity and inflation are negatively related while real activity positively influences the real return and that the negative relationship between inflation and real returns is mainly from the unexpected component of inflation.

Khurram Khan and Dr. Muhammad Rafiq (2013) ${ }^{12}$ analyzed the relationship that exists between stock prices and the cost of equity with inflation using the sample of fifty three firms and their data covering a period of ten years from 2000-2009. They found out that a positive relationship exists between stock prices and inflation, a negative relationship between cost of equity and inflation. According to the researchers, the change in stock prices is less than the inflation and 
hence stocks are a partial hedge against inflation and an increase in inflation causes earnings of the firm to increase, as a result the firm's cost of equity declines.

M. Shabriabd Masjid (2006) explored the relationship between real stock returns and inflationary trends in the Indonesian economy during the pre-1997 financial crisis period and found out a negative relationship between stock returns and inflationary trend which implies that the Indonesian stock market does not provide a good hedge against inflation. The researcher found evidence of a positive relationship between real economic activity and inflation and a negative relationship between real stock returns and real economic activity during the study period. Inflation and economic activity are correlated.

Shehu Usman Rano Aliyu (2011) examined the effect of inflation on stock market returns and volatility using monthly time series data from two West African countries, that is, Nigeria and Ghana. He investigated the impact of asymmetric shocks by using the quadratic GARCH model in both countries. He concluded that inflation rate and its three month average were found to have a significant effect on stock market volatility in the two countries. Stock market volatility and inflation are related.

\section{Methodology}

The secondary data, used for the purpose of the study, consists of 56 quarterly observations of identifying proxies of BSE consistency and WPI measured inflation. All the raw data are transformed into natural logarithms. Market capitalization is the mirror of the volume of the stock market and stand for the total outstanding shares free float by the traded price of the shares. BSE Sensex 30 denotes the performance of corporate stocks that are listed in BSE.
Value of shares traded and volume of shares traded denote the turnover and the liquidity achieved. A WPI measure of inflation is preferred as it is the official linked with both fiscal and monetary policies. It has a large representative basket of goods. It is a single index and uniform across the country. The WPI data has been collected from official websites of RBI, Handbook of statistics on Indian economy, Key Financial indicators released by RBI etc.

\section{Estimation Strategy}

The estimation strategy comprises of testing the objective by employing certain econometric techniques. Correlation analysis is done by using Karl Pearson correlation Matrix and test of significance of correlation, while co-integration relationship is investigated by using Johansen Co-integration test and vector error correction model. In order to examine the co-integrating the relationship between the two, it is a pre-requisite that that data shall not be stationary at level, but become stationary after differencing and integrated of the same order. The existence of long-run equilibrium relationship is imperative for Error correction mechanism to be conducted.

\section{Correlation Analysis}

The E Views output shows the correlation between the variables. The natural log of the raw data is used for the analysis. The correlation between inflation and BSE market cap and BSE Sensex is 23\% and 25\% respectively which shows a weak but positive relationship. The correlation between inflation and turnover, both value and volume is negligible. However, the inter-correlation between the BSE consistency indicators is positive and strong.

Table 1: Karl Pearson correlation matrix

\begin{tabular}{|l|c|c|c|c|c|}
\hline & LMCAP & LPWPI & LSENSEX & LVALUE & LVOL \\
\hline LMCAP & 1.000000 & 0.225753 & 0.992495 & 0.568382 & 0.826696 \\
\hline LPWPI & 0.225753 & 1.000000 & 0.249940 & 0.048650 & 0.032901 \\
\hline LSENSEX & 0.992495 & 0.249940 & 1.000000 & 0.589099 & 0.797172 \\
\hline LVALUE & 0.568382 & 0.048650 & 0.589099 & 1.000000 & 0.768060 \\
\hline LVOL & 0.826696 & 0.032901 & 0.797172 & 0.768060 & 1.000000 \\
\hline
\end{tabular}

\section{Johansen co-integration Test}

Table 2 shows the results of Johansen cointegration test, conducted in order to determine the relationship between market cap and WPI measure of inflation. According to the VAR Lag selection criteria, the number of lags selected is 3. Both the trace test and Max-Eigen value tests confirm that there is a 1 cointegrating equation as the probability values are less than 0.05 . Further, the computed trace statistic as well as Max-Eigen statistic are greater than 0.05 critical values. The null hypothesis that there is no cointegrating equation is rejected. The existence of $1 \mathrm{co}-$ integrating equation indicates long- run equilibrium relationship. Normalised Co-integrating coefficients shown at the bottom of the table aim to determine the long run equilibrium between WPI measure of inflation and BSE market cap. For equation BSE Market cap $=\mathrm{f}$ (inflation), the estimated $t$ value for inflation is -4.76 . This indicates that inflation is significant in explaining the changes in BSE market cap in the long run. The sign negative implies that inflation will have a negative impact on the stock market. 
Table 2: Long run relationship - Market cap and WPI inflation

Unrestricted co-integration rank trace test and max-eigen value test

\begin{tabular}{|l|c|c|c|c|c|c|c|}
\hline $\begin{array}{l}\text { Hypothesized } \\
\text { No of CE(S) }\end{array}$ & $\begin{array}{l}\text { Eigen } \\
\text { value }\end{array}$ & $\begin{array}{c}\text { Trace } \\
\text { statistic }\end{array}$ & $\begin{array}{c}\text { 0.05 } \\
\text { critical } \\
\text { value }\end{array}$ & Prob.** & $\begin{array}{c}\text { Max-Eigen } \\
\text { statistic }\end{array}$ & $\begin{array}{c}\mathbf{0 . 0 5} \\
\text { critical } \\
\text { value }\end{array}$ & Prob. ** \\
\hline None $*$ & 0.2946 & 19.9420 & 15.4947 & 0.0100 & 18.1510 & 14.2646 & 0.0116 \\
\hline At most 1 & 0.0339 & 1.7909 & 3.8415 & 0.1808 & 1.7909 & 3.8415 & 0.1808 \\
\hline
\end{tabular}

Trace test and Max-Eigen value test indicates 1 co-integrating equation at the 0.05 level.

*denotes rejection of the hypothesis at the 0.05 level

** Mackinnon-Haug-Michelis (1999) P-values

\begin{tabular}{|l|c|c|c|c|}
\hline \multicolumn{2}{|c|}{1 Co-integrating Equation(s): } & Log likelihood & $\mathbf{2 6 . 3 8 1 4 3}$ & \\
\hline \multicolumn{2}{|c|}{ Normalized co-integrating coefficients (standard error in parentheses) } \\
\hline LMCAP & LPWPI & & & \\
\hline 1.000000 & -6.534849 & & & \\
\hline & $(1.37399)$ & & & \\
\hline
\end{tabular}

(Source: Author's compilation from E Views output)

From the table 3 below, it can be found that the estimated $t$-value of the error correction term is 0.812 which is less than the critical value of t. Further, Fstatistic of 0.671, R-squared of 0.097 and log likelihood of 26.84 are not significant in the relationship. Hence, it can be concluded that there is no short run relationship between the variables under study.

Table 3: VEC for market cap and WPI inflation

\begin{tabular}{|l|l|l|l|l|}
\hline Coefficient & t-statistic & R-squared & F-statistic & Log Likelihood \\
\hline ECT & 0.812 & 0.097 & 0.671 & 26.84 \\
\hline
\end{tabular}

(Source: Author's compilation from E views output)

Table 4 shows the test results of Johansen cointegration test conducted in order to determine the relationship between BSE Sensex 30 and WPI measure of inflation. According to the VAR Lag Selection criteria, the number of lags selected is 3 . Both the trace test and Max-Eigen value tests confirm that there is a 1 co-integrating equation as the probability values are less than 0.05 . Further, the computed trace statistic as well as Max-Eigen statistic are greater than 0.05 critical values. The null hypothesis that there is no co- integrating equation is rejected. The existence of 1 cointegrating equation indicates long-run equilibrium relationship. Normalised Co-integrating coefficients shown at the bottom of the table aim to determine the long run equilibrium between WPI measure of inflation and BSE Sensex 30. For equation BSE Sensex $=\mathrm{f}$ (inflation), the estimated $t$ value for inflation is -5.32 . This indicates that inflation is significant in explaining the changes in BSE Sensex 30 in the long run. The sign negative implies that inflation will have a negative impact on the stock market.

Table 4: Long run relationship - BSE Sensex and WPI inflation

Unrestricted co-integration rank trace test and max-eigen value test

\begin{tabular}{|l|c|c|c|c|c|c|c|}
\hline $\begin{array}{l}\text { Hypothesized } \\
\text { No of CE(S) }\end{array}$ & $\begin{array}{c}\text { Eigen } \\
\text { value }\end{array}$ & $\begin{array}{c}\text { Trace } \\
\text { statistic }\end{array}$ & $\begin{array}{c}\text { 0.05 } \\
\text { critical } \\
\text { value }\end{array}$ & Prob.** & $\begin{array}{c}\text { Max- } \\
\text { Eigen } \\
\text { statistic }\end{array}$ & $\begin{array}{c}\text { 0.05 } \\
\text { critical } \\
\text { value }\end{array}$ & Prob. ** \\
\hline None $*$ & 0.3373 & 22.2993 & 15.4947 & 0.0040 & 21.3983 & $\mathbf{1 4 . 2 6 4 6}$ & 0.0032 \\
\hline At most 1 & 0.0172 & 0.9010 & 3.8415 & 0.3425 & 0.9010 & 3.8415 & 0.3425 \\
\hline
\end{tabular}

Trace test and Max-Eigen value test indicates 1 co-integrating equation at the 0.05 level.

*denotes rejection of the hypothesis at the 0.05 level

** Mackinnon-Haug-Michelis (1999) P-values

\begin{tabular}{|c|c|c|c|c|}
\hline \multicolumn{5}{|c|}{\begin{tabular}{|c|c|c|c} 
1 Cointegrating Equation(s): & Log likelihood & $\mathbf{5 0 . 1 8 1 5 5}$ & \\
Normalized cointegrating coefficients (standard error in parentheses)
\end{tabular}} \\
\hline \multicolumn{5}{|c|}{ Normalized cointegrating coefficients (standard error in parentheses) } \\
\hline LSENSEX & LPWPI & & & \\
\hline 1.000000 & -4.697298 & & & \\
\hline & $(0.88273)$ & & & \\
\hline
\end{tabular}

(Source: Author's compilation from E views output) 
From the table 5 below, it can be found that the estimated $t$-value of the error correction term is 0.941 which is less than the critical value of t. Further, Fstatistic of 1.783 , R-squared of 0.221 and log likelihood of 43.92 are not significant in the relationship. Hence, it can be concluded that there is no short run relationship between the variables under study.

Table 5: VEC for BSE sensex and WPI inflation

\begin{tabular}{|l|c|c|c|c|}
\hline Coefficient & t-statistic & R-squared & F-statistic & Log Likelihood \\
\hline ECT & 0.941 & 0.221 & 1.783 & 43.92 \\
\hline
\end{tabular}

(Source: Author's compilation from E views output)

Table 6 shows the test results of Johansen cointegration test conducted in order to determine the relationship between the BSE value of shares traded and WPI measure of inflation. According to the VAR Lag Selection criteria, the number of lags selected is 1 . Both the trace test and Max-Eigen value tests confirm that there are 2 co-integrating equations as the probability values are less than 0.05 . Further, the computed trace statistic as well as Max-Eigen statistic are greater than 0.05 critical values. The null hypothesis that there is no co-integrating equation is rejected. The existence of 2 co-integrating equations indicates longrun equilibrium relationship. Normalised Co-integrating coefficients shown at the bottom of the table aim to determine the long run equilibrium between WPI measure of inflation and BSE value of shares traded. For equation BSE value of shares traded $=\mathrm{f}$ (inflation), the estimated $\mathrm{t}$ value for inflation is -6.17 . This indicates that inflation is significant in explaining the changes in the BSE value of shares traded in the long run. The sign negative implies that inflation will have a negative impact on the stock market.

Table 6: Long run relationship- BSE value of shares traded and WPI inflation Unrestricted co-integration rank trace test and max-eigen value test

\begin{tabular}{|l|c|c|c|c|c|c|c|}
\hline $\begin{array}{c}\text { Hypothesized } \\
\text { No of CE(S) }\end{array}$ & $\begin{array}{c}\text { Eigen } \\
\text { value }\end{array}$ & $\begin{array}{c}\text { Trace } \\
\text { statistic }\end{array}$ & $\begin{array}{c}\mathbf{0 . 0 5} \\
\text { critical } \\
\text { value }\end{array}$ & Prob.** & $\begin{array}{c}\text { Max- } \\
\text { Eigen } \\
\text { statistic }\end{array}$ & $\begin{array}{c}\text { 0.05 } \\
\text { critical } \\
\text { value }\end{array}$ & Prob. ** \\
\hline None $*$ & 0.4333 & 35.0682 & 15.4947 & 0.0000 & 30.6752 & 14.2646 & 0.0001 \\
\hline At most $1^{*}$ & 0.0781 & 4.3930 & 3.8415 & 0.0361 & 4.3930 & 3.8415 & 0.0361 \\
\hline
\end{tabular}

Trace test and Max-Eigen value test indicates 2 co-integrating equation at the 0.05 level.

$*$ denotes rejection of the hypothesis at the 0.05 level

** Mackinnon-Haug-Michelis (1999) P-values

\begin{tabular}{|c|c|c|c|c|}
\hline \multicolumn{1}{|c|}{ Co-integrating Equation(s): } & Log likelihood & $\mathbf{- 1 7 . 5 1 9 3 3}$ & \\
\hline \multicolumn{2}{|c|}{ Normalized co-integrating coefficients (standard error in parentheses) } \\
\hline LVALUE & LPWPI & & \\
\hline 1.000000 & -4.116480 & & & \\
\hline & $(0.66749)$ & & & \\
\hline
\end{tabular}

of -8.21 are not significant in the relationship. Hence, it

From the table 7 below, it can be found that the estimated t-value of the error correction term is -0.052 which is less than the critical value of t. Further, Fstatistic of $0.340, \mathrm{R}$-squared of 0.020 and log likelihood

Table 7: VEC for BSE value of shares traded and WPI inflation

\begin{tabular}{|l|c|c|c|c|}
\hline Coefficient & t-statistic & R-squared & F-statistic & Log Likelihood \\
\hline ECT & -0.052 & 0.020 & 0.340 & -8.217 \\
\hline
\end{tabular}

Table 8 shows the test results of Johansen cointegration test conducted in order to determine the relationship between BSE volume of shares traded and WPI measure of inflation. According to the VAR Lag Selection criteria, the number of lags selected is 1 . Both the trace test and Max-Eigen value tests confirm that there are 2 co-integrating equations as the probability values are less than 0.05 . Further, the computed trace statistic as well as Max-Eigen statistic are greater than
0.05 critical values. The null hypothesis that there is no co-integrating equation is rejected. The existence of 2 co-integrating equations indicates long- run equilibrium relationship. Normalised Co-integrating coefficients shown at the bottom of the table aim to determine the long run equilibrium between WPI measure of inflation and BSE volume of shares traded. For the equation BSE volume of shares traded $=f$ (inflation), the estimated $t$ value for inflation is -6.16 . This indicates that inflation 
is significant in explaining the changes in BSE volume of shares traded in the long run. The sign negative

implies that inflation will have a negative impact on the stock market.

Table 8: Long run relationship- BSE volume of shares traded and WPI inflation Unrestricted co-integration rank trace test and max-eigen value test

\begin{tabular}{|l|l|l|l|l|l|l|l|}
\hline $\begin{array}{l}\text { Hypothesized } \\
\text { No of CE(S) }\end{array}$ & $\begin{array}{l}\text { Eigen } \\
\text { value }\end{array}$ & $\begin{array}{l}\text { Trace } \\
\text { statistic }\end{array}$ & $\begin{array}{l}\mathbf{0 . 0 5} \\
\text { critical } \\
\text { value }\end{array}$ & Prob.** & $\begin{array}{l}\text { Max- } \\
\text { Eigen } \\
\text { statistic }\end{array}$ & $\begin{array}{l}\mathbf{0 . 0 5} \\
\text { critical } \\
\text { value }\end{array}$ & Prob. ** \\
\hline None $*$ & 0.4392 & 35.3414 & 15.4947 & 0.0000 & 31.2283 & $\mathbf{1 4 . 2 6 4 6}$ & 0.0001 \\
\hline At most * $^{*}$ & 0.0733 & 4.1131 & 3.8415 & 0.0425 & 4.1131 & 3.8415 & 0.0425 \\
\hline
\end{tabular}

Trace test and Max-Eigen value test indicates 2 co-integrating equation at the 0.05 level.

*denotes rejection of the hypothesis at the 0.05 level

** Mackinnon-Haug-Michelis (1999) P-values

\begin{tabular}{|c|c|c|c|c|}
\hline \multicolumn{1}{|c|}{1 Co-integrating Equation(s): } & Log likelihood & $\mathbf{- 2 2 . 1 7 6 3 6}$ & \\
\hline \multicolumn{2}{|c|}{ Normalized co-integrating coefficients (standard error in parentheses) } \\
\hline LVOL & LPWPI & & & \\
\hline 1.000000 & -3.885898 & & & \\
\hline & $(0.63095)$ & & & \\
\hline
\end{tabular}

(Source: Author's compilation from E Views output)

From the table 9 below, it can be found that the estimated t-value of the error correction term is -0.742 which is less than the critical value of t. Further, Fstatistic of 0.825 , R-squared of 0.047 and log likelihood of -11.72 are not significant in the relationship. Hence, it can be concluded that there is no short run relationship between the variables under study.

Table 9: VEC for BSE volume of shares traded and WPI inflation

\begin{tabular}{|l|c|c|c|c|}
\hline Coefficient & t-statistic & R-squared & F-statistic & Log Likelihood \\
\hline ECT & -0.742 & 0.0471 & 0.825 & -11.723 \\
\hline
\end{tabular}

(Source: Author's compilation from E Views output)

\section{Conclusion and Recommendation}

This study has examined the relationship between WPI measure of inflation and BSE consistency. Coinciding with the prerequisite of a time series data, the stationarity tests and order of integration are conducted through the application of Augmented Dickey Fuller (ADF) and Philips Perron (PP) of the unit root test. All the variables other than WPI are not found stationary at level, but after differencing they have become stationary at $1^{\text {st }}$ difference. Hence, concluded that the data have become put together on the identical order. Upon investigation, the correlation test result shows that the variables were correlated accurately. The Johansen co-integration test result pointed out that there is a long run equilibrium association between the variables under study and there is no short run relationship.

The overall analysis found that the stock market may be unfavourably impacted by inflation in the long run because the inflationary pressure may retard the growth, depress the future corporate earnings and profits. Stock market being a forward looking activity, a negative relationship may threaten the stock market predictions. The study highlights that inflation becomes an important issue in the financial system needing constant management. With the recommendation of
Urjit Patel committee coming into action, inflation management becomes the responsibility of both RBI and the Government in the days ahead.

\section{References}

1. Ross Levine. Stock markets: A spur to economic growth. Paper Presented at World Bank Conference. Stock Markets, Corporate Finance and Economic growth. March 1996, pp 7-10.

2. Wikipedia (2015), "List of stock exchanges" available at wikipedia.org/wiki/list of stock exchanges, accessed on March 7, 2016.

3. Pramod Kumar Naik and Puja Padhi. (2012), The impact of macro-economic fundamentals on stock prices revisited: Evidence from Indian data. Eurasian Journal of Business and Economics. pp 25-44.

4. Yan Ting Hin, CEIC Analyst. (2014), Diverse consumption behavior between rural and urban India. ceicdata.com, accessed on March 7, 2016.

5. Bhattacharya, B and Mukherjee. Indian stock price movement and the macro-economic context - A time series analysis. Journal of International Business and Economics. 2006;5(1):167-181.

6. Bruno Solnik. The relation between stock prices and inflationary expectations: International evidence. Journal of Finance. 1983;38:35-48.

7. Carlolene Geetha, Rosle Mohidin, Vivin Vincent Chandran and Victoria Chong. The relationship between inflation and stock market: Evidence from Malaysia, United States and China. International Journal of Economics and Management Sciences. 2011;1(2):1-16. 
8. Sarbapriya Roy. Inflation and stock price behaviour in selected Asian Economies: An Econometric snapshot. Advances in Asian Social Sciences. 2012;2(1):388-397.

9. Farzad Farsio and Shokoo Feh Fazel. Can investors use inflation data to predict stock prices"? International Conference on Applied Economics. 2008;146-157.

10. Gautam Kaul. Stock returns and inflation- The role of monetary sector. Journal of Financial Economics. 1987;18;253-276.

11. K.R. Shanmugham and Biswa Swarup Mishra. Stock returns-Inflation relation in India, 1980-2004. Applied Econometrics and International Development. 2009;9(1);187-198.

12. Khurram Khan and Dr. Muhammad Rafiq. Inflation, stock prices and cost of equity" $3^{\text {rd }}$. International Conference on Management Economics and Social sciences (ICMESS). 2013;151-156. 